\title{
NETWORK ANALYSIS FOR PERFORMANCE CONTROL IN THE GOVERNANCE OF INTERCONNECTED LOCAL TRANSPORT COMPANIES
}

\author{
Laura TAMPIERI ${ }^{1, *}$, Paolo CANONICO ${ }^{2}$ \\ ${ }^{1}$ Department of Management, University of Bologna, Via Capo di Lucca 34, 40126 Bologna, Italy \\ ${ }^{2}$ Department of Economics, Management, Institutions, University of Napoli Federico II, Via Cintia, \\ 80126 Napoli, Italy
}

Received 30 November 2015; accepted 14 September 2016

\begin{abstract}
This paper discusses a network-analysis approach to the performance control of integrated built-environment systems based on efficiency, effectiveness, and adequacy. We apply this perspective to the governance of systems of local transport companies in built environments, which are frequently organized as networks. To this end, we propose a multidimensional grid of first- and second-order ties to locate network units and individuate the adequacy or appropriateness of network structures for performance control. In this field, issues connected to transport systems such as sustainability play a crucial role in defining structures and processes of network performance control. We empirically examine a pilot case of local public transport companies in the Forli-Cesena area (Italy), testing network adequacy and giving evidence for the optimal localization of governance among units dedicated to providing transport services. Our results also support the hypothesis that, although structural centralization was ostensibly oriented towards increasing governance, the structure actually devolved into decentralized control at the periphery of the network, diminishing the effectiveness of initiatives.
\end{abstract}

Keywords: built environment, transport, network, ties, governance.

\section{Introduction}

The built environment is characterized by networks of organizations with different degrees of centralization, often resulting from mergers or restructurings undertaken to increase efficiency. The impact of these networks on the built environment is connected to a growing complexity that shifts the focus from individuals' actions to those of groups, organizations, and nations - all pursuing a variety of interests that are often in conflict (Williams, 2013).

In the built environment, governance networks can facilitate coordinated action and shared opportunities in many different systems: community, transport, biological, religious, residential, business, and retail. This lends support to various social and economic activities and processes that affect the development of cities both across space and time (Brandon \& Lombardi, 2005). Furthermore, among these networks, specific ties are developed to meet the need to control and improve performance (Alexander, Andrachuk, \& Armitage, 2016). In this context, transport networks can be considered as an integral part of a fairer, more sustainable built environment, helping to drive the development of cities and the global economy on a larger scale (Banister \& Hickman, 2006). Therefore, greater emphasis on integrating transport systems into the built environment is well recognized as a contributor to better quality of life and public health (Sarkar, Webster, \& Gallacher, 2014).

The term "built environment" denotes human-made spaces that are affected by multiple factors at the micro, meso and macro levels. The corollary of this is a complex decision-making process in which multiple assessment criteria must be considered simultaneously (Kaklauskas, Tupenaite, Zavadskas, Turskis, \& Seniut, 2010).

In this paper, we study local public transport ("LPT") networks in the light of the broader concept of the built environment, in order to unpack complexity and explore these networks' profound interdependencies with decisions on urban development.

LPT clearly represents a key issue for understanding the complexity of the built environment, due to the need to integrate transportation and land use (Marti \& Weidmann, 2016). Considering LPT issues as part of policies

*Corresponding author. E-mail: laura.tampieri@unibo.it 
and decisions on the built environment significantly improves planning practices. However, to gauge the benefits of effective integration, it is essential to keep track of LPT systems' efficiency and overall performance.

Over the last 20 years, the Italian LPT sector has experienced deep and wide-ranging regulatory review, since the reform introduced by Legislative Decree $422 / 97$ (Decreto Legislativo 19 novembre 1997, n. 422 ...) (The so-called "Burlando," issued in implementation of Act no. 59/97 (Legge delega n. 59 del 15 marzo 1997 ...), revised and supplemented by the Legislative Decree. N. 400/99 (Decreto Legislativo 20 settembre 1999, n. 400 ...) and subsequent amendments). The main objective was to overcome the emergent limitations of a previous law, 151/81 (Legge quadro $n .151$ del 10 aprile 1981 ...), with four key themes: 1) decentralizing functions from the state to the regions (and from these to local authorities in a logic of subsidiarity); 2) recovery of territorial planning; 3 ) delivering sector-wide efficiency gains; and 4) liberalizing the sector by contracting out services via tenders and competition procedures (ISFORT, 2014).

In accordance with these regulatory priorities, LPT was forced to develop a wide variety of network ties based on participation, property, mergers, and the transfer of business units and service contracts between actors within the sector. These ties are based on incoming and outgoing elements of the network (mainly derived from mergers and the reallocation of business units). They represent the main sources of public-sector control over the transport system, as exercised by local authorities ("EELLs").

To explore these ties, we propose a network analysis tool based on the principle of spans of control, and on the localization of network units into either the core or periphery of the network. In this view, the governance of interconnected transport companies in the built environment relies on the ties that are created among them, and which represent the key issues for performance control. The location and movement of a company within the network derives from the dynamics of extant relationships, which create both opportunities and threats (Thornton, Henneberg, \& Naudé, 2014).

In the LPT sector, control depends on the governance of networked organizations. It is mainly concerned with efficiency, and to a lesser extent with effectiveness. To study it, we consider managerial constraints in terms of the span of control, proposing an alternative to Social Network Analysis (SNA) to locate network units within a multidimensional system. This allows us to determine the adequacy or appropriateness of network structures, and to propose governance as a central topic, based on the assumption that sustainable strategic control is connected to the localization of the leading company in the network core.

We measure the span of control, classically defined by Graiciunas (1973) as the number of organizational positions controlled by the uppermost position in the hierarchy, by the balance between the first- and second-order ties. We apply this analysis to a pilot project involving a system of local transport companies managed by ATR, the LPT agency of the Forli-Cesena basin (Italy). Our aim is to outline the optimal localization of governance among units in the period 2001-2015 by focusing on several types of ties between these units-specifically, ties based on participation, property, mergers, shifting of business units and service contracts.

In LPT, regulations individuate such connections, which then produce strengths and weaknesses from both a strategic and a managerial perspective. We focus particularly on organizational networking, distinguishing between first- and second-order ties within a multidimensional system containing ATR and its network units.

Moreover, the managerial changes resulting from the factors we explore raise the question of whether ATR and its network of companies may be labeled as a stable system, or whether the system exhibits a high degree of organizational instability. The latter conclusion is suggested by the involvement of decision-making processes and economic issues in areas such as efficiency, effectiveness, and adequacy (Hull, 2011).

Our research question is whether network units move towards the core or the periphery of the system in order to enhance governance, and how this affects performance control.

We begin by reviewing theoretical background on the built environment and its connection with the transport system, before moving on to our methodological framework. We then present out analysis of the ATR case, together with a discussion of our results and their implications for the built environment.

\section{Theoretical background}

The built environment traditionally comprises the physical artifacts and elements of human-manufactured living, working, traveling, and recreational infrastructures (Godfrey, 2010). From an organizational point of view, this concept evokes a complex and multi-layered network of ecological, social, cultural, economic, and political interorganizational relationships. These relationships operate on a variety of levels, increasing the inherent complexity, risk, and unpredictability of urban systems (Finka \& Kluvankova, 2015).

In modern society, transportation and public transit have emerged as critical issues in the built environment (Ewing \& Cervero, 2010). This is, by nature, a complex field, due to the multitude of decisions, actions, and actors involved at most or all stages of the city-building process. Hence, reflecting on issues related to transport infrastructure and urban mobility may represent a useful lens to address complexity in the built environment. Reasoning in terms of infrastructure reveals how a group of interacting, interconnected, and interdependent elements affect each other within a whole (Doloi, Crawford, Langston, \& Pheng, 2015). By taking a balanced focus on both the whole and its constituent parts, infrastructural reasoning helps us understand the world in an integrative 
manner. This view provides deep insights into how underlying relationships drive economic patterns of activity and behavior, introducing elements of change and potentially leading to a better interpretation of issues related to the built environment.

This systematic view, based on jointly interpreting the built environment, infrastructure for mobility, and transportation issues, shows how individual elements interact in a broader pattern or arrangement to trigger societal outcomes (Banister \& Berechman, 2000). By recognizing the built environment as a complex system, we highlight the importance of the interrelationships between core elements such as transportation, housing, and urban design (Preiser, 2015).

In this paper, we suggest that mobility decisions at urban level are deeply intertwined with the main features and structures of the built environment. These interconnections can contribute to key aspects of populations' quality of life, since they facilitate access to a diverse mix of infrastructure, services, and resources. Our approach is based on the idea that a network-driven view of such relationships enables us to look at the interacting behaviors of elements and actors in the urban system.

Public transport serves as an important mode of transportation in many major cities around the world (Giorgi, 2003). It has many advantages over private transportation: It takes up less road space, alleviates traffic congestion, provides mobility to urban residents, and may save commuting costs and reduce carbon emissions. Also, public transportation promotes health, for taking transit usually requires at least some walking.

Mobility lies at the core of modern countries' economic development. Decisions on how to manage it determine whether cities and industries will thrive, survive, or decline. Investments in infrastructure (roads, railways, ports, and so on) bring about significant effects in terms of economic and social growth, permanently or temporarily involving local businesses and workers in the geographical area receiving investment (Banister \& Berechman, 2001).

In fact, the development of the economy -and quality of life itself- is strongly conditioned by the way in which growing mobility needs are satisfied by transport infrastructures and properly managed transportation systems (road, rail, maritime, air, and intermodal). Transport infrastructures are invaluable social and economic assets, since they influence trade as well as industrial and residential locations. In this paper, we contend that LPT performance is a key element of the overall adequacy of the built environment, implying a powerful case for studying this issue.

Transport infrastructures are regulated at macro level, but implemented locally. They interact with a physical space and must cope with the need of citizens and businesses. From this follows the complex problem of relations between levels of competence and a variety of involved interests, bringing about negotiations and political transactions that necessarily take place between groups with different vested interests (Van der Vleuten, 2004).
In Italy, LPT is highly fragmented, due to the involvement of a number of different companies that must reorganize themselves in order to compete for tenders, form consortia and temporary partnerships, or pursue mergers and acquisitions (Incerti, 2014).

Through aggregation processes such as M\&A, the LPT sector is still seeking the appropriate configuration to reduce the problems of excessive fragmentation of supply (Della Porta \& Gitto, 2013). Such relationships are also connected to the 2015 Italian Stability Law (No 190 of 23 December 2014, Art. 1, par. 609-616), which requires local authorities to introduce operational plans for the rationalization of local subsidiaries in order to reduce their number and overall cost. Overall, the need for a more interconnected transport system, reflected in official decisions, as well as the new exigencies of the built environment in which LPT companies operate, provide the impetus for the creation of new organizational networks originating from a leader unit (Legge di stabilità $n .190 \mathrm{del}$ 23 Dicembre 2014 ...).

Transport infrastructures draw on significant resources, and their intrinsically public nature raises important policy concerns (Dunn \& Perl, 1994). The impacts of decisions on infrastructure can reverberate for decades, even centuries. Transport infrastructure planning and implementation is therefore an important issue at national and, increasingly, international level, and is characterized by interdependence among public and private actors, with conflicting interests and unpredictable outcomes.

The outcomes delivered by a transportation infrastructure depend on which public and private parties are involved, their interactions, and the resulting decisions. Sometimes transport infrastructures may be hampered by the fact that their related risks are too great and expensive to cover. Conversely, straightforward implementation processes can sometimes be explained by the fact that the parties involved underestimated the risks involved and their coverage. In such circumstances, the final outcome can be severe obstacles in the subsequent realization and exploitation phases (Mercurio, Canonico, \& Pezzillo Iacono, 2012).

Public transport infrastructures usually operate in a complex environment with several key players (Martinez, 2000 , 2003). Traditionally, organizational network studies on infrastructures make the following distinction in terms of actors: users, voters, local authorities acting as public representatives, public transport companies or operators responsible for daily management, and transport infrastructure owners. These actors fulfill a range of roles and functions in the business of passenger transport, including: supplying of a variety of services to clients (users), paying for service provision by clients (plus supplementary payment as public subsidies), and public regulation (Giorgi, 2003).

When dealing with highly intertwined public policies, the traditional concepts of markets and hierarchies as coordination mechanisms need to be revisited: we need new schemes capable of reflecting differentiated systems 
of actors. To this extent, the network research tradition points out that the implementation of public infrastructures comes from a public policy decision-making process (Kickert, Klijn, \& Koppenjan, 1997). "Interdependency" is the key word in this approach: the network concept is used to indicate patterns of relations between interdependent actors involved in processes of establishing relations within the built environment, which coalesce around policy issues and/or programs. Attention focuses on the way networks influence the development and implementation of public policy for the built environment, which means analyzing the collective action of actors. Since the network concept typically refers to interorganizational policymaking, most studies apply it at a broader level of specific policy fields.

\section{Methodological framework}

In contrast to the rich literature on network management, the concept of organizational networking is scarcely developed (Ford \& Mouzas, 2013). Moreover, empirical findings have not yet provided consolidated constructs on what shapes organizational networking (Thornton, Henneberg, \& Naudé, 2013).

Our approach is to investigate a company embedded in a business network based on different types of direct and indirect relationships that connect it to the wider relational environment. Therefore, the resources available in the network affects the firm's position within it in terms of behaviors and decisions (Burt, 2000; Zaheer \& Bell, 2005; Anderson, Håkansson, \& Johanson, 1994; Pfeffer \& Salancik, 1978).

In this context, Ritter (1999) conceptualized network competence as the means through which a company develops routines and practices to deal with its surrounding multi-company network, by managing and using business relationships according to a life cycle structured into initiation, development, and termination (Mitrega, Forkmann, Ramos, \& Henneberg, 2012; Teece, Pisano, \& Shuen, 1997).

The understanding of how a company can manage its direct relationship network is connected to the use of certain internal organizational practices that deal with the efficiency of a company's relationship portfolio. Day (1994) distinguished inside-out practices, established as internal processes, from outside-in ones, which are related to network sensing and strategizing and so externally oriented. Other authors (Holmen \& Pedersen, 2003; Zaefarian, Henneberg, \& Naudé, 2011) underlined strategic intent, citing resource mobilization and information gathering as the main drivers of organizational networking.

However, the concept of organizational networking extends beyond managing direct relationships. The structure of the network, which is related to a company's network position, generates the patterns of interactions not only with directly connected counterparts, but also with indirectly connected ones (Ford, Gadde, Håkansson, \& Snehota, 2003; Möller \& Halinen, 1999).
Direct or first-order ties do not exist in isolation (Granovetter, 1985; Ritter, 2000). They are used by a company not only to capture resources but also to mobilize those that are embedded in indirect relationships by dint of being mediated by one or more other firms (Mouzas \& Naudé, 2007; Thornton et al., 2013).

This paper asks how companies can efficiently and effectively manage such complex networks with regard to mobilizing both their direct and their indirect business ties.

On this theme, many software applications-including UCINET, NetMiner II, MultiNet, SNA, SNAP, and STRUCTURE-are used to analyze social networks. They produce graphs of network layouts based on nodes and ties, but unfortunately these representations can be hard to read, and do not always help an intuitive interpretation.

A crucial question is whether the focus of SNA should indeed be on relationships and not on other topics typically related to organizational analysis- such as power concentration and performance expressed in terms of effectiveness, the efficiency and adequacy of network control; or, in a general perspective, the strategic profile of networks. Furthermore, SNA is not merely a theory or a methodology, but a paradigm in the sense that it does not anticipate the evolution of the phenomena under analysis (Marin \& Wellman, 2011).

Many critical issues of network analysis are brought into sharper focus if we consider the organizational principles of governance unity, spans of control, and shortening lines of communication that are the main antecedents of planning macro and micro structures (Bianchi, 2007).

Authors locate the core of a network in the area where there is the highest density of ties, as opposed to the periphery, where these connections are sparser. Consequently, social network studies focus almost exclusively on the elements that drive tie-building-particularly personal ties, based on friendship for instance, that frequently arise beyond organizational assets. In these terms, SNA outlines factors distinct from the more instrumental forms of work collaboration that represent the key conditions for the effective, efficient, and adequate functioning of organizations (Bianchi \& Tampieri, 2014).

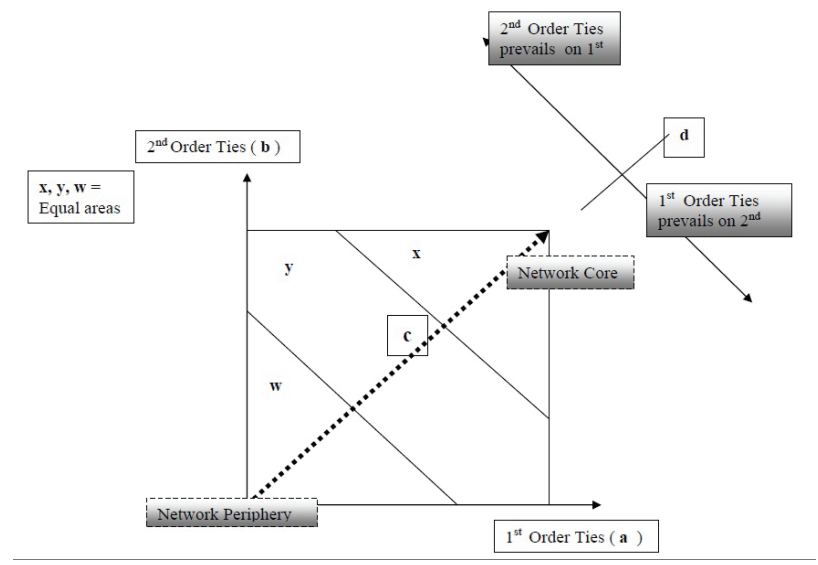

Figure 1. A grid for organizational networking analysis Bianchi and Tampieri (2014) 
We propose a multidimensional grid (Figure 1) that aims to overcome these criticisms by gathering evidence in four dimensions: a) first-order ties between units; b) second-order ties between units; c) distance from the network core; and d) the organizational complexity expressed by the relationship between first- and second-order ties. In this view, complexity mainly derives from the prevalence of first-order ties, while the prevalence of secondorder ones simplifies the network from the organizational perspective. We used this grid to empirically research transport network companies characterized by a complex system of interacting elements, in order to determine the optimal localization of governance.

In the transport sector, networks such as these are governed by internal (statutes, codes of conducts and service contracts) and external rules (concerning accounting bodies, tax accounting, civil law, and public-sector funding).

Building on this last point of view, we investigate whether the basic organizational process can be considered stable, even though our context involves a network of multiple, variously interconnected business units.

According to Gastaldi, Rossi, and Vescovi (2013) studies that configure the transportation network as a complex system of multiple interacting elements, we divide ties into five categories:

- mergers derive from the unification of two or more companies to create a new company,

- participation refers to roles and/or shares held in one company by another, in order to exercise power over it and control functions,

- property refers to the connection between local authorities (EELLs) and companies in which EELLs represent the owners,

- shifts of business units derive from the outsourcing of business units from one company to one or more others,

- contracts of service are the main instrument that regulates the relationship between the agency and the company in charge of public transport services provision. It defines the quantitative and qualitative parameters of performance.

Each of these mechanisms affects both the internal and external dimensions of the network; they often represent the attempt of public entity (EELLs) to increase or maintain the control of transport system.

Does the evolution of LPT networks meet this definition? This is the question we want to investigate, using the tools of network analysis based on managerial principles and, particularly, the span of control. It arises from the fact that the dynamic stability of a network that evolves over time can be governed less by a single central unit than by a nucleus in which the core of the network is concentrated, and which is determined by a nexus of participations and property.

For this purpose, we want to determine and track the conditions of effectiveness, efficiency, and adequacy (Figure 2).

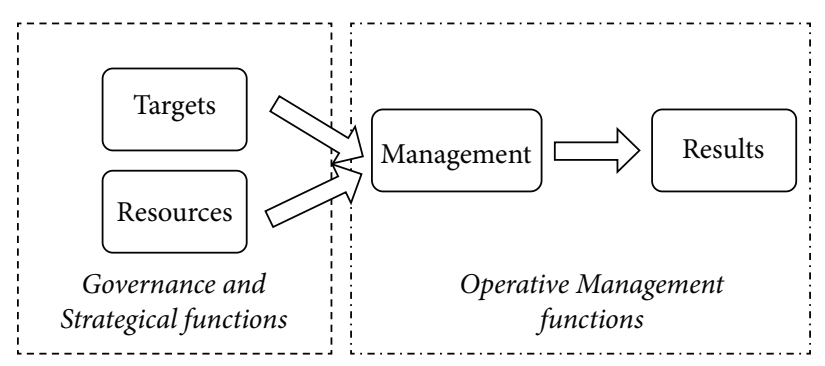

Figure 2. Elements of system performance and corresponding network functions

- effectiveness is the ratio between results and targets. It measures the attainment of targets in terms of the punctuality of buses on their routes,

- efficiency considers the relationship between results and resources, and evidences the attempt to maximize the results achieved with the resources available. For example, the ratio between the total number of accidents and the distance travelled per year (in $\mathrm{km}$ ) can be considered as a measure of efficiency, - adequacy, as the ratio between resources and targets, gauges whether the available resources are congruent with the targets set. In our context, transport systems, the percentage of vehicles with low-pollutant emissions out of the total of vehicles used is an expression of adequacy.

In such terms, effectiveness and efficiency are connected to operative management functions, as they are based on results - while adequacy is the main reference point for governance and strategic functions.

Having connected performance control to network functions, we now go on to apply it to an empirical study of transport network companies in the Forlì-Cesena basin, with the main purpose of testing the proposed multidimensional grid.

\section{An empirical study of transport network companies in the built environment}

Following previous research that applied the grid to project networks, our study focuses on the transport system by examining the network of ties managed by ATR, the local public transport (LPT) agency for the Forli-Cesena basin, Italy, over the period 2001-2015.

ATR was founded in 1975 by the Romagna Transport Consortium, and assumed the role of Mobility Agency in Forlì-Cesena Province in 2001, when it began operating in the field of public transport and collective mobility. ATR manages three urban networks: Forlì, Cesena, and Cesenatico, along with the rural network of the provincial basin; its area covers 40 municipalities and pay parking in seven municipalities.

ATR is a public economic company owned by the local authorities of the Forli-Cesena basin. It plays a planning role that places it center-stage alongside those actors who set mobility strategies (local authorities), use the services 
(clients), and deliver the service (operators). Therefore, it is a transport network unit that, as an instrument of local authorities, is subject to their directives and turns strategic decisions into specific plans for public transport development.

ATR plans and controls the public transport service and, following a public tender, relies on the outsourcing of service provision to operators. These operators are regulated by a service contract that is subject to detailed managerial control in areas including service quality, service regularity and timeliness, security, claims, and passenger control.

The network, created by ATR in 2001, includes seven units (anonymously identified as $\mathrm{A}-\mathrm{G}$ ) that are limited companies or limited liability companies operating in the transport sector. A is a limited company that was founded in 2001 for the management of LPT, 100\% owned by ATR. $\mathrm{B}$ is a limited liability company part-owned by ATR and established in 2002. C, a consortium limited company, was awarded a tender to run LPT services regulated by a service contract with ATR. D resulted from the merger of A and $\mathrm{B}$ and focuses on Forli-Cesena basin, while E and F serve Rimini and Ravenna respectively.

Moreover, D, E, and F subsequently merged into G, a limited public-transport management company that offers additional services such as the programming and planning of all or part of the production and marketing necessary for the provision of people transport; the design, production, sale, and marketing of alternative and supplementary mobility services; rental of buses (with or without drivers), boats, ferries, and passenger vehicles; and the design, construction and operation of works, infrastructure, and facilities related to public-sector transportation.

Our analysis focuses on the ties created by ATR with $\mathrm{C}$ and $\mathrm{G}$ through a service contract stipulating network performance. These three entities form a common system with targets regarding LPT and related services. In this system, the owners are the local authorities (EELLs) who are part of local society, where they wield their decisionmaking power.

In terms of performance management, ATR intervenes not only on the ground, in relation to effectiveness and efficiency once results have been achieved, but also upstream, in terms of adequacy.

In Figure 3 we evidence the main managerial changes to the network managed by ATR, through which some entities were merged or absorbed in intermediate steps, and subsequently disappeared.

The time refers to the year when network units began operations. Network ties were formed between them in an evolutionary trend, and therefore the complexity of the network is related to the coexistence of certain units/companies during the analyzed period, since they focused on different specialized activities and services. For example, $\mathrm{C}$ continued to exist after 2003 because it was part-owned by $\mathrm{E}$ and $\mathrm{F}$, and connected with the newly established $\mathrm{G}$ by the service contract beginning in 2015 .
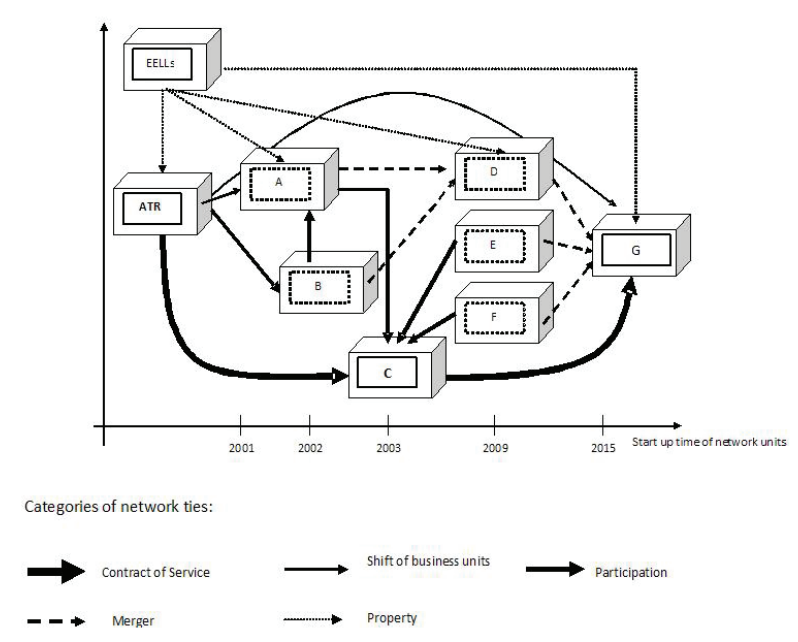

Figure 3. The evolution of the ATR network (updated to October 2015)

Thus we can outline a complex system of ties, deriving mainly from mergers and participation among the companies created by ATR. These managerial interventions are connected firstly to the legislation enacted over time (specifically the "Burlando" decree of 1997, Emilia-Romagna Law No 30 of 2 October 1998 (Legge Regionale Emilia Romagna $n .30$ del 02 ottobre 1998 ...), and No 10 of 30 June 2008 (Legge Regionale Emilia Romagna n. 10 del 30 giugno 2008 ...), and secondly to the quest for economies of scale. This is particularly clear when we consider the last stages of company aggregation in G, as well as the creation of a single area for awarding the transportation services, and the correspondent unique agency.

Our question is whether the resultant network system can be considered a basis for a stable equilibrium, owing to the persistence of interconnections among its components - despite the apparent simplification of relationships that effected a reduction in the number of network units.

To this end, we analyzed the network created by ATR by comparing its position to $\mathrm{C}$ and $\mathrm{G}$, which were linked by having the same typology of service contract, regulating financial settlements and the level of service provided in the network. We aimed to determine whether the network could be considered a stable system, or whether it exhibits instead a high degree of organizational instability, since it also encompasses decision-making and economic issues such as efficiency, effectiveness, and adequacy, creating some uncertainties in terms of performance assessment.

The analysis of the significant ties between the companies should allow us to determine whether or not the position of the main elements involved, ATR-C-G, belongs to a consistent area of governance, affording the network an appropriate level of continuity.

Considering the relationships among these units, we use a matrix A as: $\mathrm{A}=a_{i j}$ individuating first-order (direct) ties among $i ; j$ network elements (Table 1 ) to calculate second-order ties as $\mathrm{A}_{2}=a_{2 i j}$ among $i ; j$ elements (Table 2). 
Table 1. The matrix of first-order ties

\begin{tabular}{|l|c|c|c|c|c|c|c|c|c|c|}
\hline & ATR & EELLs & A & B & C & D & E & F & G & Total \\
\hline ATR & 0 & 1 & 1 & 1 & 1 & 0 & 0 & 0 & 1 & 5 \\
\hline EELLs & 1 & 0 & 1 & 0 & 0 & 1 & 0 & 0 & 1 & 4 \\
\hline A & 1 & 1 & 0 & 1 & 1 & 1 & 0 & 0 & 0 & 5 \\
\hline B & 1 & 0 & 1 & 0 & 1 & 1 & 0 & 0 & 0 & 4 \\
\hline C & 1 & 0 & 1 & 1 & 0 & 0 & 1 & 1 & 1 & 6 \\
\hline D & 0 & 1 & 1 & 1 & 0 & 0 & 0 & 0 & 1 & 4 \\
\hline E & 0 & 0 & 0 & 0 & 1 & 0 & 0 & 0 & 1 & 2 \\
\hline F & 0 & 0 & 0 & 0 & 1 & 0 & 0 & 0 & 1 & 2 \\
\hline G & 1 & 1 & 0 & 0 & 1 & 1 & 1 & 1 & 0 & 6 \\
\hline Total & 5 & 4 & 5 & 4 & 6 & 4 & 2 & 2 & 6 & 38 \\
\hline
\end{tabular}

Table 2. The matrix of second-order ties

\begin{tabular}{|l|c|c|c|c|c|c|c|c|c|c|}
\hline & ATR & EELLs & A & B & C & D & E & F & G & Total \\
\hline ATR & 5 & 2 & 3 & 2 & 3 & 4 & 2 & 2 & 2 & 25 \\
\hline EELLs & 2 & 4 & 2 & 3 & 3 & 2 & 1 & 1 & 2 & 20 \\
\hline A & 3 & 2 & 5 & 3 & 2 & 2 & 1 & 1 & 4 & 23 \\
\hline B & 2 & 3 & 3 & 4 & 2 & 1 & 1 & 1 & 3 & 20 \\
\hline C & 3 & 3 & 2 & 2 & 6 & 3 & 1 & 1 & 3 & 24 \\
\hline D & 4 & 2 & 2 & 1 & 3 & 4 & 1 & 1 & 1 & 19 \\
\hline E & 2 & 1 & 1 & 1 & 1 & 1 & 2 & 2 & 1 & 12 \\
\hline F & 2 & 1 & 1 & 1 & 1 & 1 & 2 & 2 & 1 & 12 \\
\hline G & 2 & 2 & 4 & 3 & 3 & 1 & 1 & 1 & 6 & 23 \\
\hline Total & 25 & 20 & 23 & 20 & 24 & 19 & 12 & 12 & 23 & 178 \\
\hline
\end{tabular}

These data allow us to identify the network core of the system, as illustrated in Figure 4 - defined not only by the direct links between units, but also indirect ones arising from the joint participation of components within the units that form the network.

The calculation of second-order ties is strongly affected by the structural position of first-order ones, since - according to previous studies - different basic network shapes (linear, branched, stellar and fully connected) produce different dynamics of interdependences (Bianchi \& Tampieri, 2014).

According to the multidimensional grid (Figure 1), the study highlights the fact that ATR implemented fewer first-order ties (5) than both C (6) and G (6), but more second-order ones (25) than either C (24) or G (23). This could reflect the fact that ATR is the leader organization that created the other companies, engendering greater complexity.

As indicated in Figure 4, it seems that the network core is quite crowded. Besides ATR-the formal strategic leader of the local transport system, along with EELLs (see Figure 3) - the core also includes C, G, and A: companies that are theoretically subject to ATR's control, since they are not regarded as partners with whom ATR would share strategic power.

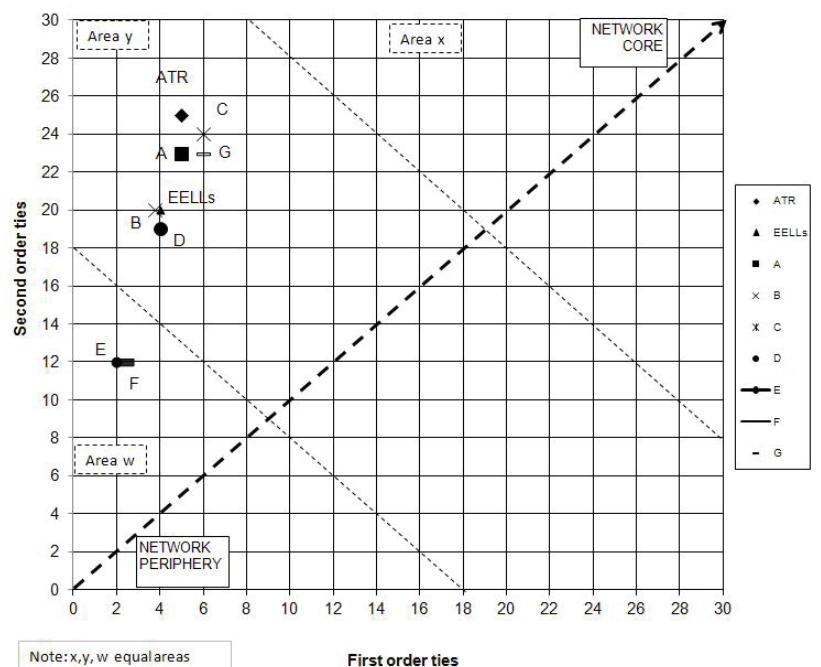

Figure 4. The location of ATR network units in the grid of analysis

Moreover, the EELLs' position is quite far from the network core. This confirms the shift of EELLs to the periphery, which was due to the network evolution that emerged in the local transport system over the last decade, driven by national regulations. 


\section{Discussion and conclusions}

Despite the formal, ostensibly central position of ATR as procurement agent, our findings seem to suggest that its substantial position is that of an intermediate body between the core and periphery of the system (Figure 4).

ATR is closer to the network periphery than $\mathrm{C}$ and $\mathrm{G}$, owing to the evolutionary process that the system has undergone. The effect is a severe impairment of ATR's ability to control the effectiveness and efficiency of the network, with implicit changes in the roles of key units and distortions of system performance (Figure 5).

The analysis confirms the progressive marginalization of ATR over the period under scrutiny, in contrast with the role originally assigned to it as local agency for mobility and local public transport, responsible for regulating the entirety of the network and its service standards. Such a marginalization could mean a weakening of governance, and consequently we can hypothesize a path towards an unstable state and problems with control.

The process has been accomplished by shifting the focus of the system towards a network core characterized by companies and with local-authority interdependences. The ties distance the operative components of the system from the area in which the control can be realized by ATR in an effective, efficient, and adequate way. The dynamics of the network can only distort these conditions, making governance and control precarious at best-not only for ATR, but also for EELLs.

Our analysis, applied to a pilot case represented by the network of ties managed by ATR in recent decades, provides evidence for the problematic localization of governance among units under its control. In particular, our findings show that, although ATR implemented a structural centralization apparently intended to strengthen governance, the structure asset, evidenced by the grid of analysis, moved towards a decentralized control process located in the network periphery, with a concomitant diminished effectiveness of initiatives.

These findings have important ramifications for the more consolidated built-environment perspectives on transportation issues, which have traditionally underestimated the role of decentralized network adaptation properties in favor of more top-down, integrated approaches (Handy, 2005).

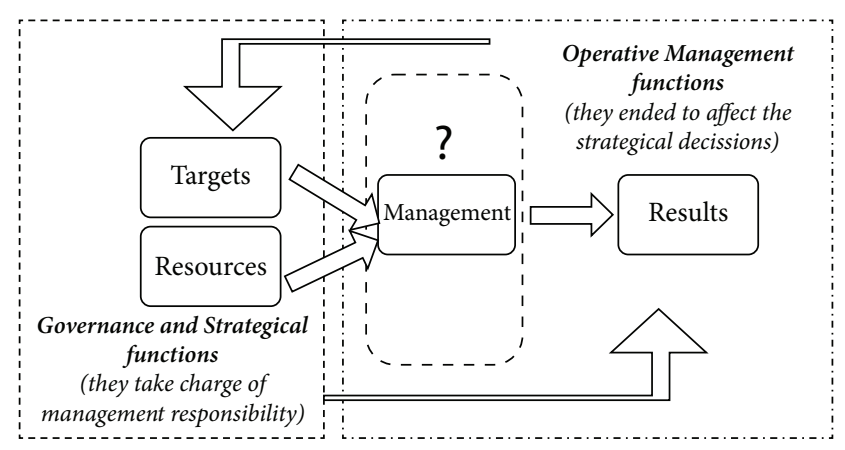

Figure 5. Distortions of system performance and network functions
Furthermore, the multidimensional analysis grid allows us to understand the appropriate way to structure networks and maintain effective governance in complex systems by considering the span of control as a concept leading to a balance between first- and second-order ties.

One limitation of our research that could be addressed by future work is the use of a particular range of connections to individuate network ties-although the selected ties, including property, service contracts and others, are in any case the tools used to promulgate strategies and orientations connected to control. Despite the variety of ties, the reason behind network evolution is the same: to increase or maintain control over a complex system. But the emergent problem is that these networks frequently didn't solve the problem of controlling performance, and indeed resulted in less-governed processes.

The potential of an approach based on our proposed analysis grid requires wider validation, not only in terms of network governance and control, but also by extension to the capability of local transport systems, considered as the network of engaged organizations, to maintain their performance in emergency situations and to absorb the unpredictable impact of movement and migrations of populations, since this seems to be the latest challenge for the transport sector and its constituent organizations.

Another limitation relates to the fact that we only analyzed data in the period 2001-2015, even though the network and its units existed for some years, and their evolution cannot be extrapolated into the immediate future, owing to the international and national regulations that significantly affect LPT policies and the strategic orientation of ATR and companies in its network.

\section{Acknowledgements}

We would like to thank ATR staff for their making themselves available to provide valuable source materials and information on the agency. We are also grateful to two anonymous reviewers for their constructive comments and advice on how to improve the paper, and to $\mathrm{ABC}$ Copywriting for copy-editing the manuscript. One of the authors gratefully acknowledges contribution provided by Programme STAR (2013, L1 Napoli_call2013_23), financially supported by UniNA and Compagnia di San Paolo.

\section{Note}

Although this paper is the result of a joint collaboration, paragraph 1 is attributed to $\mathrm{P}$. Canonico, paragraphs 2, 3 to L. Tampieri.

\section{References}

Alexander, S. M., Andrachuk, M., \& Armitage, D. (2016). Navigating governance networks for community-based conservation. Frontiers in Ecology and the Environment, 14(3), 155164. https://doi.org/10.1002/fee.1251 
Anderson, J. C., Håkansson, H., \& Johanson, J. (1994). Dyadic business relationships within a business network context. Journal of Marketing, 58(4), 1-15. https://doi.org/10.2307/1251912

Banister, D., \& Berechman, Y. (2000). Transport investment and economic development. London: UCL Press. https://doi.org/10.4324/9780203220870

Banister, D., \& Berechman, Y. (2001). Transport investment and the promotion of economic growth. Journal of Transport Geography, 9(3), 209-218. https://doi.org/10.1016/S0966-6923(01)00013-8

Banister, D., \& Hickman, R. (2006). How to design a more sustainable and fairer built environment: transport and communications. IEE Proceedings - Intelligent Transport Systems, 153(4), 276-291. https://doi.org/10.1049/ip-its:20060009

Bianchi, M. (2007). Il sistema organizzativo e le funzioni aziendali [The organizational system and corporate functions]. Torino: Giappichelli.

Bianchi, M., \& Tampieri, L. (2014). Beyond the social network analysis in the study of project networks. In F. Visintin, D. Pittino, G. Lauto, \& P. A. M. Mazzurana (Eds.), Organising for growth: theories and practices (pp. 27-32). CreateSpace Independent Publishing Platform.

Brandon, S. P., \& Lombardi, P. (2005). Evaluating sustainable development in the built environment. Oxford: Wiley Blackwell Publishing.

Burt, R. S. (2000). The network structure of social capital. Research in Organizational Behavior, 22, 345-423. https://doi.org/10.1016/S0191-3085(00)22009-1

Day, G. S. (1994). The capabilities of market-driven organizations. Journal of Marketing, 58(4), 37-52. https://doi.org/10.2307/1251915

Decreto Legislativo 19 novembre 1997, n. 422 "Conferimento alle regioni ed agli enti locali di funzioni e compiti in materia di trasporto pubblico locale, a norma dell'articolo 4, comma 4, della legge 15 marzo 1997, n. 59”, pubblicato nella Gazzetta Ufficiale n. 287 del 10 dicembre 1997 [Legislative Decree No. 422 of November 19, 1997 "Provision to the regions and local authorities of functions and tasks in the field of local public transport, in accordance with article 4, paragraph 4, of the law 15 March 1997, No. 59", published in the Official Gazette No. 287 of December 10, 1997].

Decreto Legislativo 20 settembre 1999, n. 400 "Modifiche ed integrazioni al decreto legislativo 19 novembre 1997, n. 422, recante conferimento alle regioni ed agli enti locali di funzioni e compiti in materia di trasporto pubblico locale", pubblicato nella Gazzetta Ufficiale n. 259 del 4 novembre 1999 [Legislative Decree No. 400 of September 20, 1999 "Amendments and supplements to Legislative Decree No. 422 of November 19, 1997 stating the provision to the regions and local authorities of functions and tasks in the field of local public transport", published in the Official Gazette No. 259 of November 4, 1999].

Della Porta, A., \& Gitto, A. (2013). La riforma del trasporto pubblico locale in Italia nella prospettiva aziendale. Il difficile compromesso tra economicità aziendale ed efficacia sociale [The local public transport reform in Italy in a business perspective. The difficult balance between business economy and social effectiveness]. Milano: FancoAngeli.

Doloi, H., Crawford, R., Langston, C., \& Pheng, L. S. (2015, July). A social network based framework for assessing risks and vulnerability in built environment. Proceedings of the $5^{\text {th }}$ International Conference on Building Resilience. Newcastle, Australia, 520-1-520-16.
Dunn, J. A., \& Perl, A. (1994). Policy networks and industrial revitalization: high speed rail initiatives in France and Germany. Journal of Public Policy, 14(3), 311-343. https://doi.org/10.1017/S0143814X00007303

Ewing, R., \& Cervero, R. (2010). Travel and the built environment - a meta-analysis. Journal of the American Planning Association, 76(3), 265-294. https://doi.org/10.1080/01944361003766766

Finka, M., \& Kluvankova, T. (2015). Managing complexity of urban systems: a polycentric approach. Land Use Policy, 42, 602-608. https://doi.org/10.1016/j.landusepol.2014.09.016

Ford, D., Gadde, L.-E., Håkansson, H., \& Snehota, I. (2003). Managing business relationships ( $2^{\text {nd }}$ ed.). Chichester: Wiley.

Ford, D., \& Mouzas, S. (2013). The theory and practice of business networking. Industrial Marketing Management, 42(3), 433-442. https://doi.org/10.1016/j.indmarman.2013.02.012

Gastaldi, M., Rossi, R., \& Vescovi, R. (2013). Analysing the capacity of a transportation network. A general theoretical approach, European Transport Issue 53, Paper $n^{\circ} 8$.

Giorgi, L. (2003). Sustainable mobility. Challenges, opportunities and conflicts - a social science perspective. International Social Science Journal, 55(176), 179-183. https://doi.org/10.1111/1468-2451.5502001

Godfrey, P. (2010). Using systems thinking to learn to deliver sustainable built environments. Civil Engineering and Environmental Systems, 27(3), 219-230.

https://doi.org/10.1080/10286608.2010.482656

Graiciunas, V. A. (1973). Relationship in organization. In L. Gulick \& L. Urwick (Eds.), Papers on the science of administration, Augustus M. Kelley Publ. Clifton, reprint from the first edition by Institute of Public Administration, New York.

Granovetter, M. (1985). Economic action and social structure: the problem of embeddedness. American Journal of Sociology, 91(3), 481-510. https://doi.org/10.1086/228311

Handy, S. (2005). Smart growth and the transportation-land use connection: what does the research tell us?. International Regional Science Review, 28(2), 146-167.

https://doi.org/10.1177/0160017604273626

Holmen, E., \& Pedersen, A.-C. (2003). Strategizing through analyzing and influencing the network horizon. Industrial Marketing Management, 32(5), 409-418. https://doi.org/10.1016/S0019-8501(03)00014-2

Hull, A. (2011). Transport matters, integrated approaches to planning city-regions. London: Routledge.

Incerti, R. (2014). Il nuovo volto del TLP. L'evoluzione degli assetti organizzativi ed imprenditoriali [The new face of LPT. The evolution of organizational and entrepreneurial assets] (pp. 1-15). Milano: FederMobilità.

ISFORT. (2014). Il trasporto pubblico locale. La ricerca dell'efficienza attraverso le riforme [The local public transport. The search for efficiency through reforms] (pp. 1-31). Roma: ISFORT spa.

Kaklauskas, A., Tupenaite, L., Zavadskas, E. K., Turskis, Z., \& Seniut, M. (2010). Multiple criteria assessment of alternatives for built and human environment renovation. Journal of Civil Engineering and Management, 16(2), 257-266. https://doi.org/10.3846/jcem.2010.30

Kickert, W. J. M., Klijn, E. H., \& Koppenjan, J. F. M. (1997). Managing complex networks. London: Sage.

Legge delega n. 59 del 15 marzo 1997, "Delega al Governo per il conferimento di funzioni e compiti alle regioni ed enti locali, per la riforma della Pubblica Amministrazione e per la semplificazione amministrativa", pubblicata nella Gazzetta Ufficiale 
n. 63 del 17 marzo 1997 [Delegation Act No. 59 of March 15, 1997 "Delegation to the Government for the transfer of functions and tasks to the regions and local authorities, for the reform of public administration and administrative simplification", published in the Official Gazette No. 63 of March 17, 1997].

Legge di stabilità n. 190 del 23 Dicembre 2014 "Disposizioni per la formazione del bilancio annuale e pluriennale dello Stato (legge di stabilita' 2015)", pubblicata nella Gazzetta Ufficiale n. 300 del 29 dicembre 2014 [Stability Law no. 190 of 23 December 2014 "Measures for the preparation of the annual and multiannual budget of the State (Stability Law 2015)", published in the Official Gazette No. 300 of December 29, 2014].

Legge quadro $n .151$ del 10 aprile 1981 per l'ordinamento, la ristrutturazione ed il potenziamento dei trasporti pubblici locali, pubblicata nella Gazzetta Ufficiale n. 113 del 24 aprile 1981 [Framework law No. 151 of April 10, 1981 for sorting, upgrading and enhancement of local public transport, published in the Official Gazette No. 113 of April 24, 1981].

Legge Regionale Emilia Romagna n. 10 del 30 giugno 2008 "Misure per il riordino territoriale, l'autoriforma dellamministrazione e la razionalizzazione delle funzioni" [Regional Law 30 June 2008, n. 10 "Measures for the territorial reorganization, the administration's self-reform and the rationalization of functions"].

Legge Regionale Emilia Romagna n. 30 del 02 ottobre 1998 "Disciplina generale del trasporto pubblico locale" [Regional Law Emilia Romagna October 2, 1998, No. 30, "General Discipline of local public transport"].

Marin, A., \& Wellman, B. (2011). Social network analysis. An introduction. In P. Carrington \& J. Scott (Eds.), The SAGE handbook of social network analysis. London: Sage Publications Ltd.

Marti, C. M., \& Weidmann, U. (2016, May). Understanding public transport and built environment integration at the neighbourhood scale: towards a method for holistic quantitative assessment. Proceedings of the $16^{\text {th }}$ Swiss Transport Research Conference. Monte Verità / Ascona.

Martinez, M. (2000). I modelli organizzativi e contrattuali per la pianificazione, regolazione costruzione e gestione dei sistemi di trasporto pubblico locale [The organizational and contractual models for planning, regulating the construction and operation of local public transport systems], in CESIT. Organizzazione e competizione nel trasporto locale in Europa. ROMA: Gangemi.

Martinez, M. (2003). Le agenzie di mobilità: assetto e processi organizzativi [The mobility agencies: organizational asset and processes]. Napoli: Quaderni Cesit.

Mercurio, R., Canonico, P., \& Pezzillo Iacono, M. (2012). Organising mobility as an infrastructure for development. In P. K. Kresl \& D. Ietri (Eds.), European cities and global competitiveness: strategies for improving performance. Cheltenham, UK. https://doi.org/10.4337/9780857938299.00022
Mitrega, M., Forkmann, S., Ramos, C., \& Henneberg, S. C. (2012). Networking capability in business relationships - concept and scale development. Industrial Marketing Management, 41(5), 739-751. https://doi.org/10.1016/j.indmarman.2012.06.002

Möller, K. K., \& Halinen, A. (1999). Business relationships and networks: managerial challenge of network era. Industrial Marketing Management, 28(5), 413-427.

https://doi.org/10.1016/S0019-8501(99)00086-3

Mouzas, S., \& Naudé, P. (2007). Network mobilizer. Journal of Business and Industrial Marketing, 22(1), 62-71. https://doi.org/10.1108/08858620710722833

Pfeffer, J., \& Salancik, G. R. (1978). The external control of organizations: a resource dependence perspective. New York: Harper \& Row Publisher.

Preiser, W. F. E. (2015). Programming the built environment. New York: Routledge.

Ritter, T. (1999). The networking company: antecedents for coping with relationships and networks effectively. Industrial Marketing Management, 28(5), 467-479.

https://doi.org/10.1016/S0019-8501(99)00075-9

Ritter, T. (2000). A framework for analyzing interconnectedness of relationships. Industrial Marketing Management, 29(4), 317-326. https://doi.org/10.1016/S0019-8501(00)00108-5

Sarkar, C., Webster, C., \& Gallacher, J. (2014). Healthy cities: public health through urban planning. Cheltenham: Edward Elgar Publishing, Inc. https://doi.org/10.4337/9781781955727

Teece, D. J., Pisano, G., \& Shuen, A. (1997). Dynamic capabilities and strategic management. Strategic Management Journal, 18(7), 509-533. https://doi.org/10.1002/(SICI)10970266(199708) 18:7<509::AID-SMJ882>3.0.CO;2-Z

Thornton, S. C., Henneberg, S. C., \& Naudé, P. (2013). Understanding types of organizational networking behaviors in the UK manufacturing sector. Industrial Marketing Management, 42, 1154-1166. https://doi.org/10.1016/j.indmarman.2013.06.005

Thornton, S. C., Henneberg, S. C., \& Naudé, P. (2014). Conceptualizing and validating organizational networking as a second-order formative construct. Industrial Marketing Management, 43(6), 951-966. https://doi.org/10.1016/j.indmarman.2014.05.001

Van der Vleuten, E. (2004). Infrastructures and societal change. A view from the large technical systems field. Technology Analysis \& Strategic Management, 16(3), 395-414. https://doi.org/10.1080/0953732042000251160

Williams, L. M. (2013). Getting to know the built environment as a complex system. Wellesley Institute, Canada.

Zaefarian, G., Henneberg, S. C., \& Naudé, P. (2011). Resource acquisition strategies in business relationships. Industrial Marketing Management, 40(6), 862-874. https://doi.org/10.1016/j.indmarman.2011.06.010

Zaheer, A., \& Bell, G. G. (2005). Benefiting from network position: firm capabilities, structural holes, and performance. Strategic Management Journal, 26(9), 809-825. https://doi.org/10.1002/smj.482 